\title{
Selection in the First Year of Passion Fruit Production: A Potential Strategy for Breeding
}

\author{
Luciana Domiciano Silva Rosado ${ }^{1}$, Renato Domiciano Silva Rosado ${ }^{1}$, Rosana Gonçalves Pires Matias ${ }^{1}$, \\ Carlos Eduardo Magalhães dos Santos ${ }^{1}$, Claudio Horst Bruckner ${ }^{1} \&$ Cosme Damião Cruz ${ }^{1}$ \\ ${ }^{1}$ Departament of Plant Science, Federal University of Viçosa, Brazil \\ Correspondence: Carlos Eduardo Magalhães dos Santos, Departament of Plant Science, Federal University of \\ Viçosa, Brazil. E-mail: carlos.magalhaes@ufv.br
}

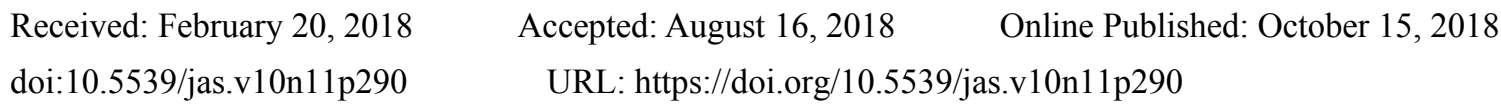

\begin{abstract}
The objective was to compare the results obtained in the first and second year of production, with the aggregate production at the end of the two years of cultivation to determine the stage of the crop cycle most suitable for selection processes. We evaluated the fruits of 26 German-sib progenies of passion fruit during the peak production of the $1^{\text {st }}$ year (December/2004) and the $2^{\text {nd }}$ year (April/2006). There was little or no difference between the means of selected families in the two production years in terms of the evaluated traits. Selection should therefore be performed in the fist production year to reduce cultivation costs, making passion fruit cultivation more economically feasible.
\end{abstract}

Keywords: Passiflora edulis, quantitative genetics, selection methods

\section{Introduction}

The passion fruit (Passiflora edulis Sims) predominates the commercial fruit cultivation in Brazil. This predominance is attributed mainly to the quality of its fruit, the plant vigor and productivity, in addition to the excellent growing conditions it finds in Brazil (Meletti, 2011).

Passion fruit production is concentrated in the South American tropics, highlighting the Brazilian production with 921,275 MT per year, although the national yield is relatively low with $13.6 \mathrm{t} \mathrm{ha}^{-1}$ in 2015 (IBGE, 2015). Despite of the high commercial demand for this fruit and its nutritional benefits, production is limited by the small number of commercial cultivars (Silva et al., 2014), with 21 registered commercial passion fruit cultivars available in Brazil (MAPA, 2016) and some local selections without registration. This number is relatively low considering the importance of Brazil as the largest global passion fruit producer and regarding the climatic variation throughout the different regions (Silva et al., 2016).

Passion fruit breeding represents a promising research field, mainly because the great variability, the relatively short cycle, and the increasing interest in this fruit facilitate its cultivation, and according Ferreira et al. (2016), these factors can enable the rapid development of new cultivars.

The passion fruit is a self-incompatible seed-propagated crop (Suassuna et al., 2003) with a large variation in terms of productivity and fruit characteristics. The improvement of genotypes with a high productivity and a high and uniform fruit quality is therefore necessary to make passion fruit economically feasible.

Favorable genetic combinations occur by chance among segregating progenies. To increase the probability of selecting superior individuals, it is necessary to work with large populations. Additionally, fruit plants require more space per individual and evaluations during some years. The ripening period may be long, especially in passion fruit, whose harvest period can reach several months. To increase the breeding efficiency in such cases, the selection of plants and/or families in the early generations can be extremely helpful (Rosal et al., 2000) and maximizes the genetic gain per unit of time (Gonçalves et al., 1998). For example, the selection of eucalypt, based on the analysis of ecophysiological traits still in juvenile stages, has been reported by Chaves et al. (2004) and Massaro et al. (2010) as viable to obtain similar results, shortening the time and the extension of field tests.

Pimentel et al. (2008) studied passion fruit selection in two production cycles and reported that the mean mass of the fruit was reduced from the first to the second cycle, indicating that plants with small fruits should be 
discarded in the first production cycle, thereby reducing the labor input in the selection procedures in the second production cycle.

This way, breeding programs, in general, should be dynamic, fast, and economically efficient, and the efficiency can be improved with constant upgrading of the selection mechanisms (Silva \& Pereira, 2011). Gonçalves et al. (1998) reported that most of the costs of breeding programs for perennial species are a result of the long evaluation process. Any reduction in costs may increase the financial viability of the breeding program.

Moraes et al. (2014) reported that the occurrence of high genetic correlations, significant for traits in evaluation periods, favor the holding of early selection. For example, for common bean, Pádua et al. (2015) report that the early selection for anthracnose resistance in the initial stages of the breeding program promotes benefits since it allows to eliminate the susceptive plants, which usually present low grain yields, in the first generations of selection and, consequently, to reduce the expenses in the advanced generations.

In this context, this study compared the results obtained after selection performed in the first and in the second production year, with aggregate production at the end of the two years. The overall goal was to determine the most suitable selection stage of the passion fruit cycle in terms of saving time and resources.

\section{Material and Methods}

\subsection{Site Characterization}

The experiment was conducted in the Plant Science Department of the University Federal of Viçosa, Viçosa, Minas Gerais. The municipality is located at $20^{\circ} 45^{\prime} \mathrm{S}, 42^{\circ} 52^{\prime} \mathrm{W}, 648 \mathrm{~m}$ above sea level. The climate is classified as type Cwa (mesothermal climate, Köppen), with an average annual rainfall of 1,200 $\mathrm{mm}$ and an average temperature of $19^{\circ} \mathrm{C}$.

\subsection{Biological Material}

We analyzed 26 full-sib progenies of passion fruit in a randomized block design with three replications. Each plot had four plants, with a row distance of $3.5 \mathrm{~m}$ and a distance between plants of $3.5 \mathrm{~m}$, totaling 815 plants/ha. The plants were trained in a vertical support structure with one wire gauge 12 , fixed at a height of $1.80 \mathrm{~m}$. The usual cultural practices were applied.

\subsection{Evaluated Traits}

The fruits were harvested when more than $30 \%$ of the skin surface showed a yellow color. The evaluated traits were as follows: number of fruits per plant (NF), obtained by counting the fruits during the peak production of the $1^{\text {st }}$ year (December 2004) and the $2^{\text {nd }}$ year (April 2006), estimated production (EP) in $\mathrm{kg} / \mathrm{plant}$, estimated by the product of the mean fruit mass by the number of fruits per plant, mass of the fruit (MF), obtained by weighing the fruits on a digital balance in grams (g), mass of the skin (MS), obtained by weighing the skins on a digital balance in grams (g), mass of the pulp plus seeds (MP), based on the difference between fruit mass and mass of the skin ( $M P=M F-M S)$ in grams $(\mathrm{g})$, length (LL), measuring the longitudinal axis of the fruit, using a digital caliper, in millimeters $(\mathrm{mm})$, equatorial diameter (ED), obtained by measuring in the equatorial region of the fruit, using a digital caliper, in millimeters (mm), and thickness of the skin (TS), measured in the middle portion of the cut fruit by using a digital caliper in millimeters $(\mathrm{mm})$. Except for the number of fruits per plant and estimated production, the traits were measured in a sample of 10 fruits per plant for each cultivation year.

\subsection{Data Analysis}

The data were submitted to analysis of variance based on the model in blocks, with information from individuals within the plot. The promising plants were identified by selection among families in unbalanced experiments; the percentage of selection among families in each year was $24 \%$, totaling six better families. We compared the families selected according to evaluations from the first and the second year, and the results from both evaluation years were aggregated to determine the stage of the cycle most propitious for carrying out the evaluations.

The factors estimated were mean of population, mean of families selected, and the selection gain in each year. The selection gain $(\mathrm{SG})$ was estimated using the following equation:

$$
S G=\left(X_{S}-X_{0}\right) h^{2}
$$

where $X_{S}$ is the mean of the families selected in each year and $h^{2}$ is the heritability of each year.

Considering that the selected family in a year amounts to selecting this throughout the cycle, the average values of the aggregate results were used to calculate the global gain projection (GGP), according to the following equation:

$$
G G P=\left(\bar{X}_{S Y}-\bar{X}_{S T o t a l}\right) h_{\text {total }}^{2}
$$


where, $\bar{X}_{S Y}$ is the mean of the totals of the families selected in each year, $\bar{X}_{\text {STotal }}$ is the mean of the families selected on aggregate of years, and $\mathrm{h}_{\text {total }}^{2}$ is the heritability of the two years combined.

Analysis of variance and selection were performed using the software Genes; the selection procedure was combined for various environments, according to Cruz (2013).

\section{Results and Discussion}

According to the results of the analysis of variance, there was significant genetic variance among the families at $1 \%$ probability by the test $\mathrm{F}$ for all traits. Santos et al. (2008) reported the occurrence of genetic variability in passion fruit for disease resistance and plant vigor and considered this an essential condition for the establishment of an effective breeding program in order to improve horticultural traits.

Reducing the costs of passion fruit breeding programs through the ideal number of plots has been presented by Stork et al. (2014), who concluded that to assess properties in passion fruit, independent of the genotype, the optimum plot size is less than five plants. However, it is preferable to use less than five plants per plot to evaluate most of the properties of passion fruit. The number of replicates is calculated as a function of the desired accuracy. In addition, the number of plants per experiment is lower when using the optimal number of plants per plot. Although the reduction of plots results in decreased costs, progeny selection in the $1^{\text {st }}$ year of passion fruit production has not yet been described.

With this in mind, the selection was performed to increase the number of fruits per plant, estimated production, mass of the fruit, mass of the pulp, length and equatorial diameter and to decrease skin mass and thickness. In terms of the number of fruits per plant, nine families were selected based on data of the two production years, of which three were common among the years and for estimated production eight families were selected, being four were common among the years of production. The projection of global gains showed no difference in the selection between the first year and the aggregate result for both traits, but in the second year, there was a reduction in the average value (Table 1 ). 
Table 1. Full-sib families of passion fruit selected by selection among and within 2 years of production to the number of fruits per plant and estimated production

\begin{tabular}{|c|c|c|c|c|c|c|c|c|c|c|c|c|}
\hline \multirow{3}{*}{ Traits } & \multirow{3}{*}{ Selection Family } & \multicolumn{3}{|c|}{ Selection } & & \multicolumn{3}{|c|}{ Means } & & \multicolumn{3}{|c|}{ Mean total of 2 years of production } \\
\hline & & \multicolumn{2}{|c|}{ Year } & \multirow{2}{*}{ Total } & & \multicolumn{2}{|c|}{ Year } & \multirow{2}{*}{ Total } & & \multicolumn{2}{|c|}{ Year } & \multirow{2}{*}{ Total } \\
\hline & & $1^{\text {st }}$ & $2^{\text {nd }}$ & & & $1^{\text {st }}$ & $2^{\text {nd }}$ & & & $1^{\mathrm{st}}$ & $2^{\text {nd }}$ & \\
\hline \multirow{12}{*}{ 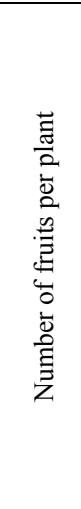 } & 2 & Yes & No & Yes & & 94 & 89 & 183 & & 183 & $-*$ & 183 \\
\hline & 5 & Yes & No & Yes & & 84 & 110 & 188 & & 188 & - & 188 \\
\hline & 11 & Yes & Yes & Yes & & 96 & 137 & 233 & & 233 & 233 & 233 \\
\hline & 13 & Yes & Yes & Yes & & 118 & 162 & 280 & & 280 & 280 & 280 \\
\hline & 15 & No & Yes & No & & 40 & 113 & 148 & & - & 148 & - \\
\hline & 18 & No & Yes & Yes & & 43 & 122 & 152 & & - & 152 & 152 \\
\hline & 19 & Yes & No & No & & 71 & 100 & 149 & & 149 & - & - \\
\hline & 20 & No & Yes & No & & 31 & 123 & 128 & & - & 128 & - \\
\hline & 23 & Yes & Yes & Yes & & 76 & 129 & 184 & & 184 & 184 & 184 \\
\hline & & & & & $\overline{\mathrm{X}}_{0}$ & 53 & 96 & 140 & $\overline{\bar{X}}_{\mathrm{SY}}$ & 202 & 187 & 203 \\
\hline & & & & & $\mathrm{h}^{2}$ & 0.54 & 0.27 & 0.58 & & & & \\
\hline & & & & & SG & 19.9 & 9.4 & 36.5 & GGP & -0.58 & -9.28 & - \\
\hline \multirow{11}{*}{ 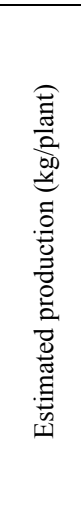 } & 2 & Yes & No & Yes & & 19.6 & 18.4 & 38.0 & & 38.0 & - & 38.0 \\
\hline & 5 & Yes & Yes & Yes & & 18.8 & 25.2 & 42.6 & & 42.6 & 42.6 & 42.6 \\
\hline & 11 & Yes & Yes & Yes & & 20.1 & 30.3 & 50.4 & & 50.4 & 50.4 & 50.4 \\
\hline & 13 & Yes & Yes & Yes & & 24.6 & 39.2 & 63.8 & & 63.8 & 63.8 & 63.8 \\
\hline & 16 & Yes & No & No & & 13.1 & 19.2 & 32.4 & & 32.4 & - & - \\
\hline & 18 & No & Yes & Yes & & 9.12 & 30.0 & 36.2 & & - & 36.4 & 36.4 \\
\hline & 19 & Yes & Yes & Yes & & 16.4 & 22.9 & 34.4 & & 34.4 & 34.4 & 34.4 \\
\hline & 23 & No & Yes & No & & 12.6 & 22.9 & 31.9 & & - & 31.9 & - \\
\hline & & & & & $\overline{\mathrm{X}}_{0}$ & 10.9 & 20.0 & 29.0 & $\bar{X}_{S Y}$ & 43.6 & 43.2 & 44.2 \\
\hline & & & & & $\mathrm{h}^{2}$ & 0.60 & 0.33 & 0.62 & & & & \\
\hline & & & & & GS & 4.74 & 2.87 & 9.42 & GGP & -0.37 & -0.62 & - \\
\hline
\end{tabular}

$\overline{\text { Note. }}$ *Absent value indicates that the family was not selected based on data from the years in question. $\overline{\mathrm{X}}_{0}=$ mean of population; $\mathrm{h}^{2}=$ heritability of each year; $\mathrm{SG}=$ selection gain; $\overline{\mathrm{X}}_{\mathrm{SY}}=$ mean of selected each year. GGP $=$ global gain projection.

Similarly, for fruit mass, pulp mass, and skin mass, we selected eight families, with four families being common between the selection years (Table 2). However, the global gain projection was negative when the selection was performed in the first year, but the values were of low magnitude. 
Table 2. Full-sib families of passion fruit selected by selection among and within 2 years of production to the mass of the fruit, pulp and skin

\begin{tabular}{|c|c|c|c|c|c|c|c|c|c|c|c|c|}
\hline \multirow{3}{*}{ Traits } & \multirow{3}{*}{ Selection Family } & \multicolumn{3}{|c|}{ Selection } & \multicolumn{4}{|c|}{ Means } & \multicolumn{4}{|c|}{ Mean total of 2 years of production } \\
\hline & & \multicolumn{2}{|c|}{ Year } & \multirow{2}{*}{ Total } & & \multicolumn{2}{|c|}{ Year } & \multirow{2}{*}{ Total } & & \multicolumn{2}{|c|}{ Year } & \multirow{2}{*}{ Total } \\
\hline & & $1^{\text {st }}$ & $2^{\text {nd }}$ & & & $1^{\text {st }}$ & $2^{\text {nd }}$ & & & $1^{\text {st }}$ & $2^{\text {nd }}$ & \\
\hline \multirow{11}{*}{ 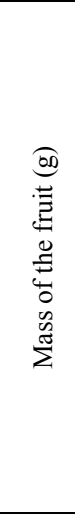 } & 4 & Yes & No & No & & 230.1 & 202.1 & 216.1 & & 216.1 & - & - \\
\hline & 5 & Yes & Yes & Yes & & 229.1 & 229.7 & 228.3 & & 228.3 & 228.3 & 228.3 \\
\hline & 7 & Yes & Yes & Yes & & 234.8 & 225.4 & 229.7 & & 229.7 & 229.7 & 229.7 \\
\hline & 13 & No & Yes & Yes & & 221.2 & 235.7 & 228.5 & & - & 228.5 & 228.5 \\
\hline & 17 & Yes & Yes & Yes & & 229.6 & 224.1 & 226.4 & & 226.4 & 226.4 & 226.4 \\
\hline & 18 & No & Yes & Yes & & 227.7 & 245.6 & 232.6 & & - & 232.6 & 232.6 \\
\hline & 19 & Yes & Yes & Yes & & 227.7 & 225.1 & 226.4 & & 226.4 & 226.4 & 226.4 \\
\hline & 24 & Yes & No & No & & 228.7 & 220.3 & 218.3 & & 218.3 & - & - \\
\hline & & & & & $\overline{\mathrm{X}}_{0}$ & 212.7 & 201.3 & 204.7 & $\overline{\mathrm{X}}_{\mathrm{SY}}$ & 224.2 & 228.6 & 228.6 \\
\hline & & & & & $\mathrm{h}^{2}$ & 0.49 & 0.68 & 0.73 & & & & \\
\hline & & & & & SG & 8.4 & 20.1 & 17.4 & GGP & -3.2 & - & - \\
\hline \multirow{11}{*}{ 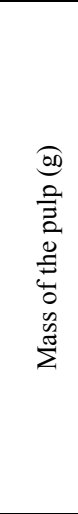 } & 3 & Yes & No & No & & 105.8 & 85.3 & 91.4 & & 91.4 & - & - \\
\hline & 5 & Yes & Yes & Yes & & 106.7 & 113.9 & 110.0 & & 110.0 & 110.0 & 110.0 \\
\hline & 7 & Yes & No & Yes & & 109.7 & 95.5 & 102.3 & & 102.3 & - & 102.3 \\
\hline & 11 & No & Yes & No & & 101.0 & 99.5 & 100.2 & & - & 100.2 & - \\
\hline & 13 & Yes & Yes & Yes & & 105.5 & 109.8 & 107.7 & & 107.7 & 107.7 & 107.7 \\
\hline & 17 & Yes & Yes & Yes & & 113.1 & 102.3 & 107.7 & & 107.7 & 107.7 & 107.7 \\
\hline & 18 & No & Yes & Yes & & 105.0 & 114.1 & 106.9 & & - & 106.9 & 106.9 \\
\hline & 19 & Yes & Yes & Yes & & 116.6 & 113.5 & 114.7 & & 114.7 & 114.7 & 114.7 \\
\hline & & & & & $\overline{\mathrm{X}}_{0}$ & 96.0 & 87.6 & 90.7 & $\overline{\mathrm{X}}_{\mathrm{SY}}$ & 105.6 & 107.8 & 108.2 \\
\hline & & & & & $\mathrm{h}^{2}$ & 0.38 & 0.66 & 0.68 & & & & \\
\hline & & & & & SG & 5.1 & 14.0 & 11.9 & GGP & -1.8 & -0.3 & - \\
\hline \multirow{11}{*}{ 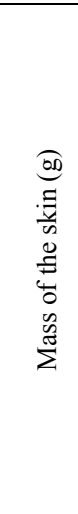 } & 1 & No & Yes & No & & 109.1 & 98.6 & 103.1 & & - & 103.1 & - \\
\hline & 8 & No & Yes & Yes & & 113.2 & 97.8 & 98.0 & & - & 98.0 & 98.0 \\
\hline & 10 & Yes & Yes & Yes & & 93.1 & 90.6 & 91.0 & & 91.0 & 91.0 & 91.0 \\
\hline & 15 & Yes & Yes & Yes & & 106.7 & 94.1 & 95.6 & & 95.6 & 95.6 & 95.6 \\
\hline & 20 & Yes & No & No & & 107.2 & 99.2 & 103.2 & & 103.2 & - & - \\
\hline & 21 & Yes & Yes & Yes & & 98.2 & 94.0 & 94.0 & & 94.0 & 94.0 & 94.0 \\
\hline & 22 & Yes & Yes & Yes & & 106.0 & 92.3 & 96.3 & & 96.3 & 96.3 & 96.3 \\
\hline & 23 & Yes & No & Yes & & 97.0 & 101.5 & 102.1 & & 102.1 & - & 102.1 \\
\hline & & & & & $\overline{\mathrm{X}}_{0}$ & 116.9 & 113.7 & 114.4 & $\overline{\mathrm{X}}_{\mathrm{SY}}$ & 105.6 & 107.8 & 108.2 \\
\hline & & & & & $\mathrm{h}^{2}$ & 0.61 & 0.70 & 0.78 & & & & \\
\hline & & & & & SG & -9.6 & -13.3 & 14.2 & GGP & -2.0 & -0.3 & - \\
\hline
\end{tabular}

Note. *Absent value indicates that the family was not selected based on data from the years in question. $\overline{\mathrm{X}}_{0}=$ mean of population; $h^{2}=$ heritability of each year; $S G=$ selection gain; $\bar{X}_{\mathrm{SY}}=$ mean of selected each year. GGP $=$ global gain projection.

In terms of skin thickness, 10 families were selected, with two being common between the years; global gain projection of the first year was higher than that of the second year. For longitudinal length and equatorial diameter, eight families were selected for the two production years, of which four families were common between years (Table 3). The global gain projection of the first year in relation to the second was greater for longitudinal length, but negative for equatorial diameter, with values close to zero.

Means of fruit number per plant and estimated production of the families selected based on the first year were similar compared to those selected based on the production of the two years, indicating the possibility that the selection for these traits can be made in the first year, saving time and resources (Table 1). The global gain projection estimated per cycle presents reducing for number of fruits per plant of first by second year, however 
are similar for estimated production, but considering that the selection cycle will be reduced from two to one years, the genetic gain per year will increase. Another benefit is the possibility of recombining the selected plants after elimination of the less productive ones, increasing the expected genetic gain in subsequent steps of the program.

Pimentel et al. (2008) reported a high positive correlation between fruit number and estimated production per plant; the selection for prolific plants indirectly enabled the selection for increased productivity. Bruckner et al. (2002) reported that the production of fruits increases from the first to the second year of production, but decreases in the third year. In terms of breeding purposes, the question is whether the early-selection plants are useful for the selection of more productive plants in a shorter time and with less labor consumption. Our data support a positive answer because the global gains projections per cycle were similar, but higher per year by selecting, based on the data of the first year.

Melo et al. (2001) reported that in passion fruit production, the second year showed the highest productivity because the plants were in full vegetative growth and had a high number of fruit branches.

However, the implementation of the selection of promising genotypes should be performed in the first year to reduce the costs of implementing the breeding program, allowing the selection of plants in the first year and the recombination of genotypes in the second year of production, as recommended by the methodology of recurrent selection. For Eucalyptus spp., with a rotation age of 7 years in tropical regions, Beltrame et al. (2012) and Pavan et al. (2014) suggest the early selection of hybrid clones in the third year after planting, maximizing the genetic selection gain with the same financial resources and human resources available.

Rosal et al. (2000) reported that the early selection of families of bean were effective, especially in the elimination of the worst families, thus reducing the work of breeders in advanced generations. Similarly, Clement et al. (2015) report that selection in cotton from early generations, based on a single plant stage, provides subsequent population size reduction for fiber quality.

In perennial species, such as rubber trees, selection procedures have been done after long periods of evaluation of the individuals. Gonçalves et al. (1998) observed for that specie that selection went with to 2 years showed better efficiency, providing a superior gain per unit time and proving to be an early selection strategy in the breeding of these species.

Melo et al. (2011) reported that in any breeding program, reducing the time spent obtaining superior genotypes is of fundamental importance. Progeny selection in the $1^{\text {st }}$ year of production could be an important strategy to reduce costs for fruit selection and to allocate resources within the second year in others stages of the breeding program for passion fruit. 
Table 3. Full-sib families of passion fruit selected by selection among and within 2 years of production to the thickness of the skin, longitudinal length and equatorial diameter

\begin{tabular}{|c|c|c|c|c|c|c|c|c|c|c|c|c|}
\hline \multirow{3}{*}{ Traits } & \multirow{3}{*}{ Selection Family } & \multicolumn{3}{|c|}{ Selection } & \multicolumn{4}{|c|}{ Means } & & \multicolumn{3}{|c|}{ Mean total of 2 years of production } \\
\hline & & \multicolumn{2}{|c|}{ Year } & \multirow{2}{*}{ Total } & & \multicolumn{2}{|c|}{ Year } & \multirow{2}{*}{ Total } & & \multicolumn{2}{|c|}{ Year } & \multirow{2}{*}{ Total } \\
\hline & & $1^{\mathrm{st}}$ & $2^{\text {nd }}$ & & & $1^{\text {st }}$ & $2^{\text {nd }}$ & & & $1^{\text {st }}$ & $2^{\text {nd }}$ & \\
\hline \multirow{13}{*}{ 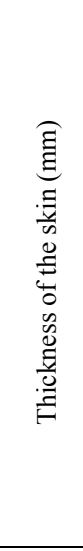 } & 1 & No & Yes & Yes & & 4.67 & 3.96 & 3.63 & & - & 3.63 & 3.63 \\
\hline & 2 & No & Yes & No & & 5.07 & 4.17 & 4.62 & & - & 4.62 & - \\
\hline & 5 & Yes & No & No & & 4.57 & 4.60 & 4.55 & & 4.55 & - & - \\
\hline & 8 & No & Yes & Yes & & 4.83 & 4.21 & 4.32 & & - & 4.32 & 4.32 \\
\hline & 9 & No & Yes & Yes & & 5.01 & 4.25 & 4.51 & & - & 4.51 & 4.51 \\
\hline & 11 & Yes & No & Yes & & 4.52 & 4.44 & 4.48 & & 4.48 & - & 4.48 \\
\hline & 13 & Yes & No & No & & 4.60 & 4.80 & 4.70 & & 4.70 & - & - \\
\hline & 17 & Yes & Yes & Yes & & 3.95 & 4.10 & 4.06 & & 4.06 & 4.06 & 4.06 \\
\hline & 19 & Yes & Yes & Yes & & 3.93 & 3.86 & 3.89 & & 3.89 & 3.89 & 3.89 \\
\hline & 26 & Yes & No & No & & 4.57 & 4.77 & 4.70 & & 4.70 & - & - \\
\hline & & & & & $\overline{\mathrm{X}}_{0}$ & 4.88 & 4.47 & 4.58 & $\overline{\mathrm{X}}_{\mathrm{SY}}$ & 4.40 & 4.17 & 4.15 \\
\hline & & & & & $\mathrm{h}^{2}$ & 0.35 & 0.24 & 0.35 & & & & \\
\hline & & & & & SG & -0.18 & -0.09 & -0.15 & GGP & 0.08 & 0.01 & - \\
\hline \multirow{11}{*}{ 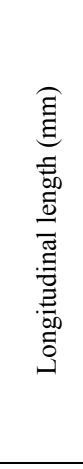 } & 5 & Yes & Yes & Yes & & 100.9 & 96.0 & 97.5 & & 97.5 & 97.5 & 97.5 \\
\hline & 6 & No & Yes & No & & 93.8 & 93.7 & 93.7 & & - & 93.7 & - \\
\hline & 7 & Yes & No & No & & 95.3 & 93.3 & 94.1 & & 94.1 & - & - \\
\hline & 11 & Yes & Yes & Yes & & 95.9 & 95.2 & 95.5 & & 95.5 & 95.5 & 95.5 \\
\hline & 13 & Yes & Yes & Yes & & 94.6 & 95.5 & 95.0 & & 95.0 & 95.0 & 95.0 \\
\hline & 16 & Yes & No & Yes & & 95.7 & 93.7 & 94.7 & & 94.7 & - & 94.7 \\
\hline & 17 & Yes & Yes & Yes & & 94.5 & 94.5 & 94.5 & & 94.5 & 94.5 & 94.5 \\
\hline & 18 & No & Yes & Yes & & 93.0 & 96.4 & 94.3 & & - & 94.3 & 94.3 \\
\hline & & & & & $\overline{\mathrm{X}}_{0}$ & 90.1 & 88.6 & 89.1 & $\bar{X}_{\mathrm{SY}}$ & 95.3 & 95.1 & 95.2 \\
\hline & & & & & $\mathrm{h}^{2}$ & 0.83 & 0.83 & 0.87 & & & & \\
\hline & & & & & $\mathrm{SG}$ & 5.0 & 5.6 & 5.3 & GGP & 0.1 & -0.1 & - \\
\hline \multirow{11}{*}{ 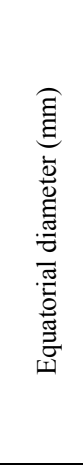 } & 2 & Yes & No & No & & 80.2 & 79.3 & 79.8 & & 79.8 & - & - \\
\hline & 4 & Yes & No & No & & 82.1 & 76.9 & 79.4 & & 79.4 & - & - \\
\hline & 5 & Yes & Yes & Yes & & 80.2 & 81.0 & 80.5 & & 80.5 & 80.5 & 80.5 \\
\hline & 7 & Yes & Yes & Yes & & 81.1 & 81.2 & 81.0 & & 81.0 & 81.0 & 81.0 \\
\hline & 17 & No & Yes & Yes & & 79.9 & 80.2 & 80.1 & & - & 80.1 & 80.1 \\
\hline & 24 & Yes & Yes & Yes & & 80.3 & 81.1 & 80.8 & & 80.8 & 80.8 & 80.8 \\
\hline & 25 & No & Yes & Yes & & 79.9 & 82.2 & 81.8 & & - & 81.8 & 81.8 \\
\hline & 26 & Yes & Yes & Yes & & 82.7 & 80.5 & 80.9 & & 80.9 & $\begin{array}{r}80.9 \\
\end{array}$ & 80.9 \\
\hline & & & & & $\overline{\mathrm{X}}_{0}$ & 78.4 & 77.5 & 77.7 & $\overline{\mathrm{X}}_{\mathrm{SY}}$ & 80.4 & 80.8 & 80.8 \\
\hline & & & & & $\mathrm{h}^{2}$ & 0.55 & 0.68 & 0.60 & & & & \\
\hline & & & & & SG & 1.5 & 2.4 & 1.9 & GGP & -0.2 & - & - \\
\hline
\end{tabular}

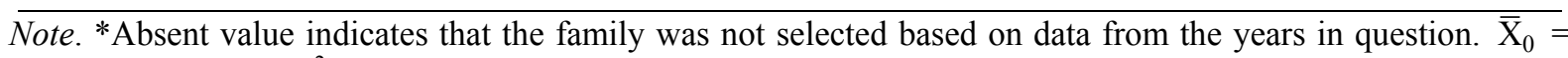
mean of population; $\mathrm{h}^{2}=$ heritability of each year; $\mathrm{SG}=$ selection gain; $\overline{\mathrm{X}}_{\mathrm{SY}}=$ mean of selected each year. GGP $=$ global gain projection.

\section{Conclusions}

For all evaluated traits, we observed little or no difference between the means of selected families in the two production years. This indicates that the selection in the first year of production led to results similar to those found by selection in the second year.

\section{References}

Beltrame, R., Bisognin, D. A., Mattos, B. D., Cargnelutti Filho, A., Haselein, C. R., Gatto, D. A., \& Santos, G. A. dos. (2012). Desempenho silvicultural e seleção precoce de clones de híbridos de eucalipto. Pesquisa Agropecuária Brasileira, 47(6), 791-796. https://doi.org/10.1590/S0100-204X2012000600009 
Bruckner, C. H., Meletti, L. M. M., Otoni, W. C., \& Zerbini Júnior, F. M. (2002). Maracujazeiro. In C. H. Bruckner (Ed.), Melhoramento de fruteiras tropicais (pp. 373-409). Viçosa, Brazil: Editora UFV.

Chaves, J. H., Reis, G. G. dos R., Reis, M. das G. F., Neves, J. C. L., Pezzopane, J. E. M., \& Polli, H. Q. (2004). Seleção precoce de clones de eucalipto para ambientes com disponibilidade diferenciada de água no solo: relações hídricas de plantas em tubetes. Revista Árvore, 28(3), 333-341. https://doi.org/10.1590/S0100-676 22004000300003

Clement, J. D., Constable, G. A., Striller, W. N., \& Liu, S. M. (2015). Early generation selection strategies for breeding better combinations of cotton yield and fibre quality. Field Crops Research, 172, 145-152. https://doi.org/10.1016/j.fcr.2014.11.009

Cruz, C. D. (2013). GENES-A software package for analysis in experimental statistics and quantitative genetics. Acta Scientiarum, 35(3), 271-276.

Ferreira, R. T., Viana, A. P., Silva, F. H. de L. E., Santos, E. A., \& Santos, J. O. (2016). Intrapopulation recurrent selection in sour passion fruit by mixed models. Revista Brasileira de Fruticultura, 38(1), 158-166. https://doi.org/10.1590/0100-2945-260/14

Gonçalves, P. de S., Bortoletto, N., Fonseca, F. da S., Bataglia, O. C., \& Ortolani, A. A. (1998). Early selection for growth vigor in rubber tree genotypes in northwestern São Paulo State (Brazil). Genetics and Molecular Biology, 21(4), 620-630. https://doi.org/10.1590/S1415-47571998000400018

IBGE (Instituto Brasileiro de Geografia e Estatística). (2015). Produção Agrícola Municipal: Culturas temporárias e permanentes. Retrieved October 28, 2016, from http://biblioteca.ibge.gov.br/visualizacao/ periodicos/66/pam_2015_v42_br.pdf

MAPA (Ministério da Agricultura, Pecuária e Abastecimento). (2016). Registro Nacional de Cultivares. Retrieved November 12, 2016, from http://www.extranet.agricultura.gov.br/php/snpc/cultivarweb/ cultivares_regis.php

Massaro, R. A. M., Bonine, C. A. V., Scarpinati, E. A., \& Paula, R. C. de. (2010). Viabilidade de aplicação da seleção precoce em testes clonais de Eucalyptus spp. Ciência Florestal, 20(4), 597-609. https://doi.org/ $10.5902 / 198050982418$

Meletti, L. M. M. (2011). Avanços na cultura do maracujá no Brasil. Revista Brasileira de Fruticultura, 33(SP. 1), 83-91. https://doi.org/10.1590/S0100-29452011000500012

Melo, D. S., Pinto, C. A. B. P., Peixoto, L. S., Neder, D. G., \& Assis, J. C. de (2011). Early selection of full-sib potato families. Ciência e Agrotecnologia, 35(6), 1101-1109. https://doi.org/10.1590/S1413-70542011000 600009

Melo, K. T., Manica, I., \& Junqueira, N. T. V. (2001). Produtividade de seis cultivares de maracujazeiro-azedo durante três anos em Vargem Bonita, DF. Pesquisa Agropecuária Brasileira, 36(9), 1117-1125. https://doi.org/10.1590/S0100-204X2001000900005

Moraes, C. B. de, Freitas, T. C. M. de, Pieroni, G. B., Resende, M. D. V. de, Zimback, L., \& Mori, E. S. (2014). Estimativas de parâmetros genéticos para seleção precoce de clones de Eucalyptus para região com ocorrência de geadas. Scientia Forestalis, 42(102), 219-227.

Pádua, J. M. V, Ramalho, M. A. P., \& Abreu, A. de F. B. (2015). Implications of early selection for resistance to anthracnose in genetic breeding of common bean. Crop Breeding and Applied Biotechnology, 15(3), 169-174. https://doi.org/10.1590/1984-70332015v15n3a29

Pavan, B. E., Paula, R. C. de, Perecin, D., Scarpinati, E. A., \& Candido, L. S. (2014). Early selection in open-pollinated Eucalyptus families based on competition covariates. Pesquisa Agropecuária Brasileira, 49(6), 483-492. https://doi.org/10.1590/S0100-204X2014000600010

Pimentel, L. D., Stenzel, N. M. C., Cruz, C. D., \& Bruckner, C. H. (2008). Seleção precoce de maracujazeiro pelo uso da correlação entre dados de produção mensal e anual. Pesquisa Agropecuária Brasileira, 43(10), 1303-1309. https://doi.org/10.1590/S0100-204X2008001000007

Rosal, C. J. de S., Ramalho, M. A. P., Gonçalves, F. M. A., \& Abreu, A. de F. B. (2000). Seleção precoce para a produtividade de grãos no feijoeiro. Bragantia, 59(2), 189-195. https://doi.org/10.1590/S0006-8705 2000000200010 
Santos, C. E. M. dos, Pissioni, L. L. M., Morgado, M. A. D., Cruz, C. D., \& Bruckner, C. H. (2008). Estratégias de seleção em progênies de maracujazeiro-amarelo quanto ao vigor e incidência de verrugose. Revista Brasileira de Fruticultura, 30(2), 444-449. https://doi.org/10.1590/S0100-29452008000200030

Silva, G. O. da, \& Pereira, A. da S. (2011). Seleção em gerações iniciais para caracteres agronômicos em batata. Horticultura Brasileira, 29(4), 449-455. https://doi.org/10.1590/S0102-05362011000400001

Silva, F. H. L., Muñoz, P. R., Vincent, C. I., \& Viana, A. P. (2016). Generating relevant information for breeding Passiflora edulis: Genetic parameters and population structure. Euphytica, 208(3), 609-619. https://doi.org/ 10.1007/s10681-015-1616-8

Silva, F. H. L., Viana, A. P., Ferreira, R. T., Freitas, J. C. O., Santos, J. O., \& Rodrigues, D. L. (2014). Measurement of genetic diversity in progenies of sour passion fruit by Ward-MLM methodology: A strategy for heterotic group formation. Ciência e Agrotecnologia, 38(3), 1234-1239. https://oi.org/10.1590/ S1413-70542014000300003

Suassuna, T. M. F., Bruckner, C. H., Carvalho, C. R., \& Borém, A. (2003). Self-incompatibility in passionfruit: evidence of gametophytic-sporophytic control. Theoretical and Applied Genetics, 106(2), $298-302$. https://doi.org/10.1007/s00122-002-1103-1

Storck, L., Lúcio, A. D., Krause, W., Araújo, D. V de, \& Silva, C. A. (2014). Scaling the number of plants per plot and number of plots per genotype of yellow passion fruit plants. Acta Scientiarum, 36(1), 73-78. https://doi.org/10.4025/actasciagron.v36i1.17697

\section{Copyrights}

Copyright for this article is retained by the author(s), with first publication rights granted to the journal.

This is an open-access article distributed under the terms and conditions of the Creative Commons Attribution license (http://creativecommons.org/licenses/by/4.0/). 